\title{
Yield, quality and nutrient accumulation in watermelon as a function of organo-mineral fertilization
}

Francisco Sales Oliveira Filho ${ }^{*}$, Francisco Hevilásio Freire Pereira ${ }^{2}$, Marcos Eric Barbosa Brito ${ }^{3}$, Joyce Emanuele Medeiros², Francisco Hélio Dantas Lacerda², José Eustáquio Campos Júnior ${ }^{2}$

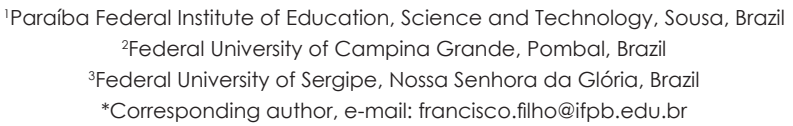

\begin{abstract}
The study aimed to assess the yield, nutrients accumulation and fruit quality of watermelon grown under different NPK rates provided by mineral and organic fertilizers. The experiment was performed at the Federal University of Campina Grande (UFCG), Campus Pombal-PB, during the period from June to September 2013. Treatments consisted of three nutrient concentrations N, $P$ and $K(50,100$ and $150 \%$ of NPK recommendation for watermelon) and five ratios of mineral and organic fertilizer (100/0, 75/25, 50/50, $25 / 75$ to 0/100). The experimental design was in randomized blocks, in a $3 \times 5$ factorial scheme with four replicates. The NPK rate corresponding to $100 \%$ was $120 \mathrm{~kg} \mathrm{ha}^{-1}$ respectively for $\mathrm{N}, \mathrm{P}$ and $\mathrm{K}$. The following variables were evaluated: fruit yield, nutrient accumulation, titratable acidity, soluble solids and ratio between soluble solids and titratable acidity. The concentration of $150 \%$ of nutrients was more effective in increasing the yield for the $75 / 25,25 / 75$ and $0 / 100$ ratios of mineral and organic fertilizers, and the concentrations of 100 and $150 \%$ were the most effective in the accumulation of soluble solids when applied in the mineral and organic fertilizer ratios of $75 / 25$ and 50/50.
\end{abstract}

Keywords: Citrullus lanatus, manure, fertilizers, mineral nutrition

\section{Introduction}

The watermelon, Citrullus lanatus, such as other olericulture produces, has in mineral nutrition of the main factors that directly influence the increase of yield and quality of fruits (Barros et al., 2012). Plant nutrition is directly influenced by the composition of the substrate utilized, with the levels of mineral nutrients being available according to the higher or lower amount of fertilizer added to the soil (Carvalho et al., 2012). Among fertilizers, the mineral industrialized fertilizers are the most utilized. However, when poorly managed, they increase the production costs and cause undesirable effects in the environment, such as the pollution of water reservoirs and streams and the salinization of the soils in semiarid regions.

The use of organic materials as alternative raw-material for the production of fertilizers is a strategic action in the environmental perspective, being convenient provided that it is also viable in the economical point of view (Naeem et al., 2006; Galvão et al., 2008; Santos et al., 2012). Among the large diversity of organic materials used in agriculture, bovine manure is a widely adopted alternative for the supply of nutrients, mainly nitrogen and phosphorus, in family farming areas of the semiarid and agreste regions of the 
Northeast of Brazil (Menezes \& Salcedo, 2007; Rodrigues et al., 2008). For Ouda \& Mahadeen (2008) the use of locally produced manure may increase the yield of crops with lower use of mineral fertilizers.

Doses of organic fertilizers that maximize yield and decrease production costs, complemented with mineral fertilizers, can be established for regional conditions, aiming the improvement of physical, chemical and biological properties of the soil, cost reduction with fertilization (Rodrigues\& Casali, 1999) and consequent improvement in the supply of macro and micronutrients to the plants (Albuquerque et al., 2010). Although scarce, some studies have been performed, in some Brazilian states, aiming to assess the effect of the combined application of natural and organic fertilizers on olericulture crops. Leão et al., (2008), evaluating different levels of organic and mineral fertilization, observed a lower yield of the water melon variety Crimson Sweet when these were used in isolate. Mueller et al. (2013), in their studies with organic fertilizer with and without mineral fertilization, in the cultivation of tomato, observed higher commercial yields obtained with the application of either the mineral fertilization or the organic fertilizer complemented with mineral fertilizer.
In view of the foregoing, the aim of this paper was to evaluate the influence of the fertilization with growing NPK doses applied through mineral and organic fertilizers in different ratios on the components of production, quality and accumulation of nutrients in watermelon cultivated in the semiarid of the Paraíba state.

\section{Material and methods}

The experiment was installed in an area of the Center of Sciences and Agri-food Technology of the Federal University of Campina Grande (CCTA/UFCG) in the period from May to July 2013, located in the municipality of PombalPB, with coordinates $6^{\circ} 48^{\prime} 16^{\prime \prime} \mathrm{S}$ and $37^{\circ} 49^{\prime}$ $15^{\prime \prime} \mathrm{W}$, and elevation of $144 \mathrm{~m}$. The soil of the experimental area is classified as fluvent neosol. The climate of the region, according to the Köpen-Geiger classification, is of the Aw' type, that is, hot and dry with summer-autumn rainfall (semiarid).

Before the installation of the experiment, chemical analyses of the soil were performed in the Laboratory of Soil Fertility and Plant Nutrition of the Federal University of the Semiarid, in Mossoró-RN, with its chemical characteristics being described in Table 1.

Table 1. Chemical characteristics of the soil in the $0-20 \mathrm{~cm}$ depth layer of the experimental area

\begin{tabular}{|c|c|c|c|c|c|c|c|c|c|c|}
\hline $\mathrm{pH}$ & $P$ & $\mathrm{~K}^{+}$ & $\mathrm{Na}^{+}$ & $\mathrm{Ca}^{2+}$ & $\mathrm{Mg}^{2+}$ & $\mathrm{Al}^{3+}$ & $\mathrm{H}^{+}+\mathrm{Al}^{3+} \mathrm{SB}$ & $T$ & $\mathrm{~V}$ & PST \\
\hline $\mathrm{H}_{2} \mathrm{O}$ & $\mathrm{MgC}$ & 3 ------ & 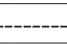 & ----- & $\mathrm{cmol}_{\mathrm{c}}$ & $m^{-3}-$ & - & -- & $\%$ & $\%$ \\
\hline 6.8 & 43.6 & 0.35 & 0.41 & 19.6 & 5.28 & 0.0 & 3.05 & 42869 & 89 & 1 \\
\hline
\end{tabular}

The treatments were constituted of three percentages $\left(50,100\right.$ and $150 \%$ ) of the $\mathrm{N}, \mathrm{P}_{2} \mathrm{O}_{5}$ and $\mathrm{K}_{2} \mathrm{O}$ doses recommended by Cavalcante (2008) for watermelon, provided through mineral (M) and organic (O) fertilizers, respectively, applied in different ratios (0/100, 75/25, 50/50 $25 / 75$ and $100-M / 0-0)$. The $100 \%$ dose based on the recommendation for the watermelon crop, having as parameter the chemical analysis of the soil, consisted of $120 \mathrm{~kg} \mathrm{ha}^{-1}$ for $\mathrm{N}, \mathrm{P}_{2} \mathrm{O}_{5}$ and $\mathrm{K}_{2} \mathrm{O}$. In the implantation of the experiment the

Table 2.Chemical characteristics of the dairy cattle manure.

\begin{tabular}{|c|c|c|c|}
\hline M.S. & $\mathrm{N}$ & $\mathrm{P}_{2} \mathrm{O}_{5}$ & $\mathrm{~K}_{2} \mathrm{O}$ \\
\hline \multicolumn{4}{|c|}{ - } \\
\hline 88 & 10.8 & 0.36 & 1.2 \\
\hline
\end{tabular}


The amount of organic fertilizer (dairy cattle manure) corresponding to $100 \%$ of the NPK recommendation was defined as a function of the contents of Total- $\mathrm{N}, \mathrm{P}\left(\mathrm{P}_{2} \mathrm{O}_{5}\right)$ and $\mathrm{K}\left(\mathrm{K}_{2} \mathrm{O}\right)$ present in the dry matter of the material. Based on the $100 \%$ values the amounts for the remaining percentages corresponding to the respective treatments were calculated. For the calculations regarding the amount of manure, the expression proposed by Furtini Neto etal. (2001) was used, and after calculated the amount of organic fertilizer as a function of the N, P and K macronutrients, individually, the calculation of the mean was performed, whose value was defined as $100 \%$ of the recommendation. The amounts of manure as a function of the macronutrient contents observed in this material were 5,263; 87,719 and $13,158 \mathrm{Kg} \mathrm{ha}^{-1}$ respectively for the contents of $\mathrm{N}, \mathrm{P}$ and $\mathrm{K}$, and the mean was $36,000 \mathrm{Kg} \mathrm{ha}^{-1}$.

Once defined the amounts of organic fertilizer for each treatment, the fertilizer was distributed in the planting row and incorporated to the soil in a single time, 15 days before the transplantation. After the incorporation of the manure, daily irrigation was established, using drip tapes with a spacing of $30 \mathrm{~cm}$ within emitters and flow rate of $1.7 \mathrm{~L}$ per hour.

The mineral fertilizers were applied through fertigation using venturi fertilizer injectors, partitioned throughout the crop cycle. The phosphate fertilizer (MAP) was partitioned into three parcels, with the first application performed one day before transplantation and the remainder in the two weeks afterwards. The balancing was performed in order to identify the amount of nitrogen applied through MAP, with the amount to be applied divided into eight applications throughout the crop cycle, utilizing the urea fertilizer as source. The $\mathrm{KCl}$-applied potassium was distributed into ten applications: $10 \%$ in basal dressing, $10 \%$ in the first two weeks (5\% per week), $40 \%$ from the third to the sixth week (10\% per week), $30 \%$ in the seventh and eighth weeks ( $15 \%$ per week) and $10 \%$ in the ninth and tenth weeks (5\% per week).

The fertilization was performed with micronutrients, calcium, magnesium and sulfur, common to all treatments. The irrigation management was performed based on the estimative of the daily reference crop evapotranspiration (ETo), which was obtained from climatic data of a semiautomatic weather station installed nearby the experimental place. The daily irrigation depth was calculated in such a way as to replace the losses through evapotranspiration of the crop calculated for each development stage of the plant. Soil preparation, remaining cultural practices and phytosanitary controls were performed in accordance with the needs and recommendations for the watermelon crop.

The seedlings were produced in polystyrene trays of 128 cells, using a commercial substrate. Commercial watermelon seeds of the 'Olímpia' hybrid were utilized. The transplantation was performed when the plantlets presented two definitive well-formed leaves, what happened at 13 days after sowing. The watermelon plants were conducted in the spacing of $2,0 \times 0,60 \mathrm{~m}$, with the floor area of each experimental unit being constituted of a $6 \mathrm{~m}$ row containing ten plants, with the 8 central plants being considered for the evaluations.

The accumulation of nutrients was determined after the drying of the leaves, stems and fruits, collect at 68 DAT, when these were grinded and analyzed as to the contents of nitrogen, phosphorus and potassium macronutrients, according to the methodology utilized by Silva (2009). The analyses of the vegetal material were performed in the Laboratory of Soils and Plant Nutrition of the CCTA/UFCG, Pombal-PB. For the evaluation of production, six plants per parcel were utilized, in which were only considered commercial fruits those collected with weight over $4 \mathrm{Kg}$, with no injuries or phytosanitary problems. For the chemical analyses of the fruits, pulp samples from two fruits per experimental unit were collected, with a slice being removed in the longitudinal direction of the fruit, from the apex to the posterior extremity, and homogenized in multiprocessor to obtain its juice. Based on this, the following characteristics were determined: soluble solids (SS), titratable acidity (TA), and SS/TA ratio. The soluble solids were determined through refractometry, with the results being expressed in percentage; for the titratable acidity, $2 \mathrm{~mL}$ of the juice were pipetted in $50 \mathrm{~mL}$ of distilled 
water with two drops of phenolphthalein, and titrated with solution of sodium hydroxide at 0,1 $M$, standardized and under stirring until obtaining a pink coloration persistent for 30s, with the results expressed in percentage of citric acid; the SS/ TA ratio was obtained through the division of the soluble solids content by the titratable acidity.

The data were subjected to analysis of variance, and the means were compared by Tukey's test, at 5\% probability. The SAEG 9.1 version software was utilized,

\section{Results and Discussion}

There was a significant interaction between the factors NPK concentration and ratios of mineral and organic fertilizer on the accumulation of Nitrogen (N), Phosphorus (P) and Potassium $(K)$ in the stem of the watermelon plants (Figure 1). From the unfolding of the interaction
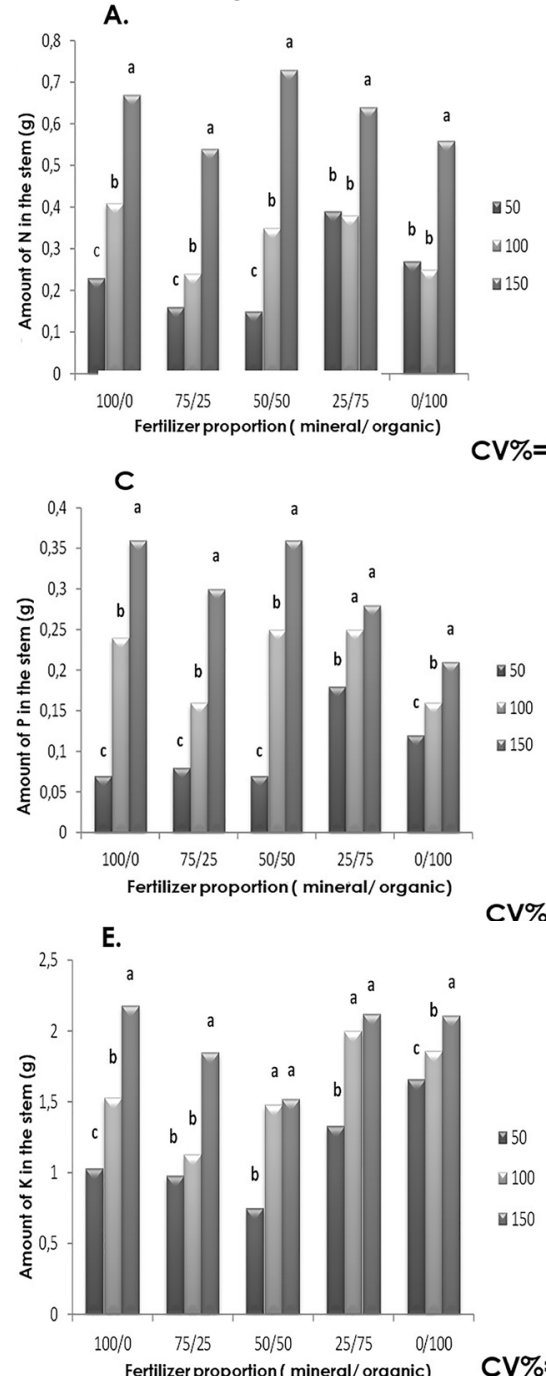

Figure1.Nitrogen ( $A$ and $B$ ), phosphorus ( $C$ and $D$ ) and potassium ( $E$ and $F$ ) amounts in the watermelon stem as a function of the different nutrient concentrations applied through mineral and organic fertilization.

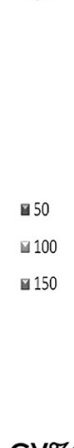

$C V \%=17.40$

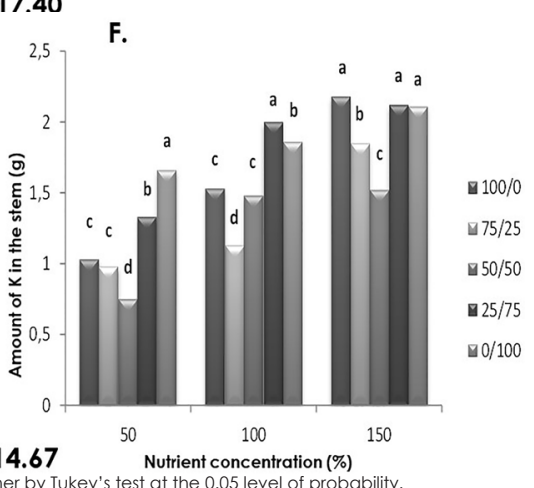

between the two factors, it was verified that for all fertilizer ratios the highest nutrient concentration (150\%) provided the highest accumulation of $\mathrm{N}$, with the 50/50 ratio providing the highest value $\left(0,73 \mathrm{~g} \mathrm{plant}^{-1}\right)$ followed by the 100/0 and 25/75 ratios, whose values were respectively 0,67 and $0,64 \mathrm{~g} \mathrm{plant}^{-1}$ (Figure 1A and 1B). A similar result was observed for the accumulation of $\mathrm{P}$ and $\mathrm{K}$ in the stem, in which the concentration of $150 \%$ in the different ratios also favored the higher accumulation of these nutrients. For the 100/0 and 50/50 ratios the amounts of $P$ observed in the stem were similar, with value of 0,36 $\mathrm{g} \mathrm{plant}^{-1}$ (Figure 1C and 1D).

As for $K$, the 100/0, 25/75 and $0 / 100$ ratios in the $150 \%$ concentration provided the highest amounts of this element, with values of 2,18; 2,12 and 2,1 $1 \mathrm{~g} \mathrm{plant}^{-1}$ respectively (Figure $1 \mathrm{E}$ and $1 \mathrm{~F}$ ).
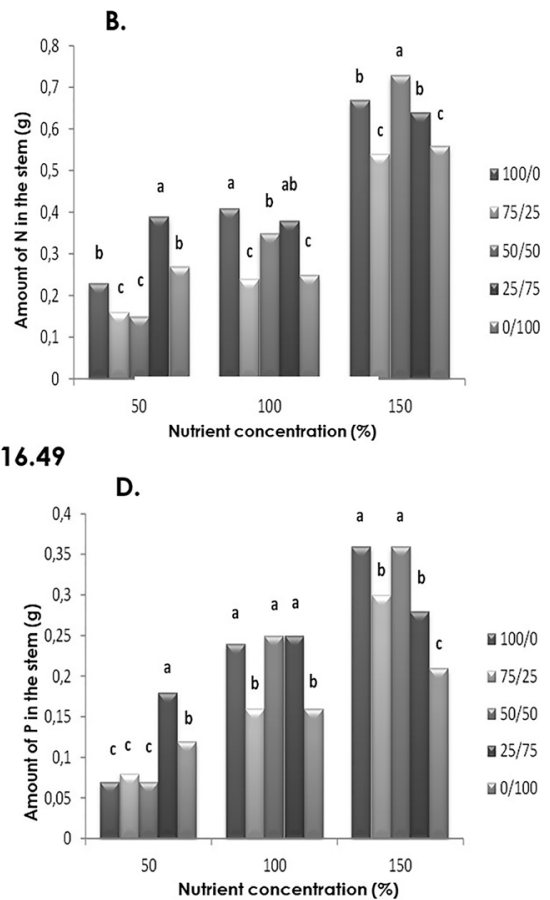

Com. Sci., Bom Jesus, v.x, n.x, p.x-x, xxx./xxx. 2018 
Based on the results concerning the higher exportation of $\mathrm{N}$ and $\mathrm{P}$ by the stem, when utilized only the mineral fertilizer, these might be attributed to the fact that these materials are highly soluble and readily available for the plant. Since the application was partitioned into different amounts throughout the crop cycle, it might have favored the absorption of these nutrients in the different growth stages. The 25/75 ratio might have benefited manure mineralization due to the supply of nutrients to the microorganisms of the soil, thus attenuating the process of nutrient immobilization and making the $\mathrm{N}$ and $\mathrm{P}$ nutrients more readily available for absorption by the watermelon plants. It has been verified that the incorporation of organic matter to the soil is able to rapidly adsorb the phosphorus applied as fertilizer, thus increasing $P$ availability (Guppy et al., 2005).

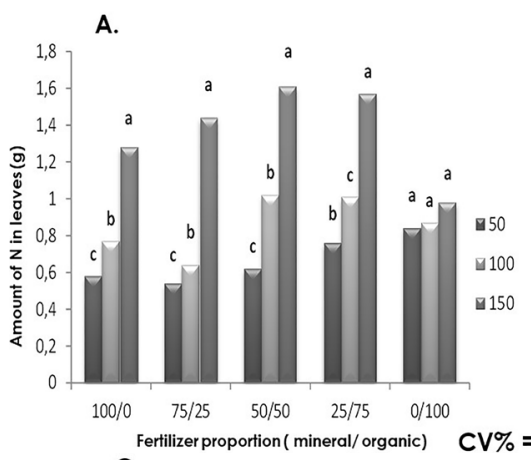

c.

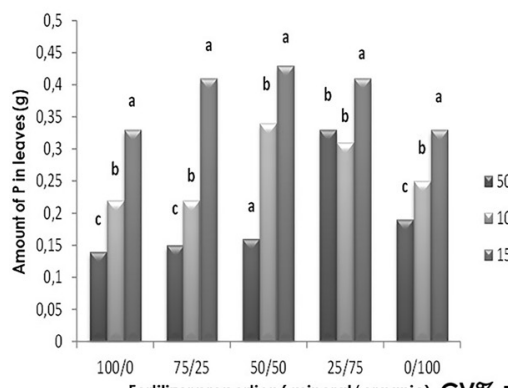

Fertilizer proportion ( mineral/organic) $\mathrm{CV} \%=18.38$

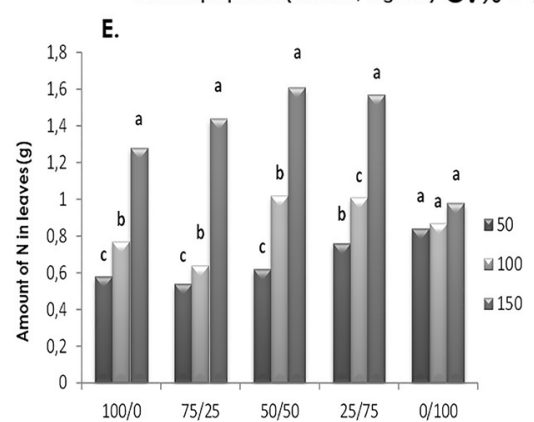

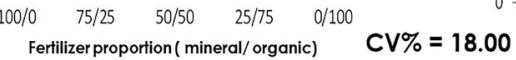

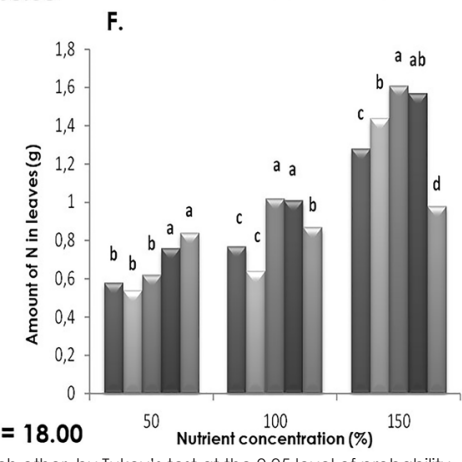

Tukey's test at the 0.05 level of probabilty. Figure 2. Nitrogen ( $A$ and $B$ ), phosphorus ( $C$ and $D)$ and potassium ( $E$ and $F$ ) amounts in watermelon leaves as a function of the different nutrient concentrations applied through mineral and organic fertilization. observed for all treatments. similar results to these of the present work.

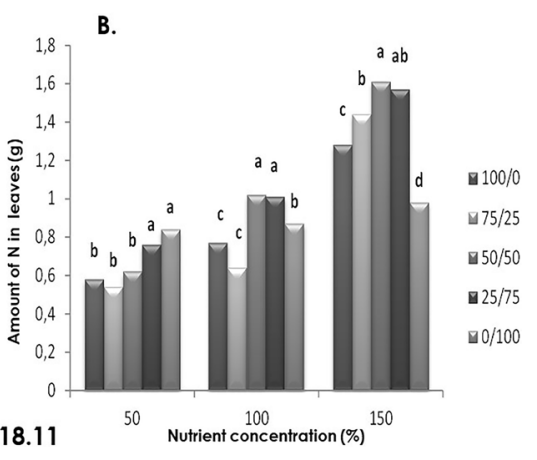

D.

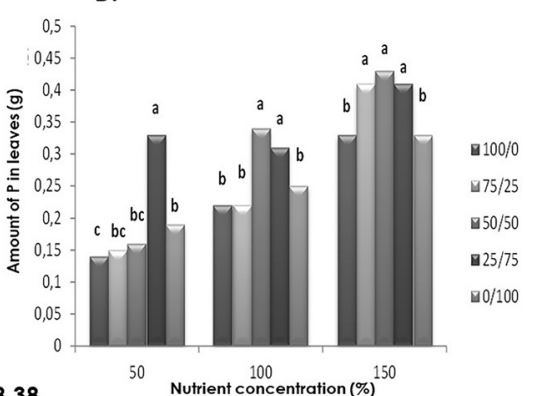
$\square 100 / 0$ $\square 75 / 25$ $\square 50 / 50$ 由 $25 / 75$ $\square 0 / 100$

With regard to K, it may be deduced, based on the data, that the similar exportation between the treatment in which only the mineral fertilizer was used and that in which only the organic fertilizer was used is due to the fact that this nutrient does not belong to organic compounds, being easily released into the soil solution (Taiz\&Zeiger, 2009). Generally, a decreasing accumulation order of $K, N$ and $P$ is

For the accumulation of $\mathrm{N}, \mathrm{P}$ and $\mathrm{K}$ in the leaves, a significant interaction was observed between the analyzed factors (Figure 2). A decreasing accumulation order of $K, N$ and $P$ in the leaf is observed for all treatments. Grangeiro \& Cecilio Filho (2005), when evaluating the accumulation and exportation of macronutrients by the seedless watermelon hybrid, observed 
The $150 \%$ concentration favored the higher accumulation of $\mathrm{N}$ and $\mathrm{P}$ in the leaves, in all evaluated ratios. However, the 75/25, 50/50 and $25 / 75$ ratios provided the highest values, namely $1,44,1,61$ and 1,57 of $N$ per plant, and $0,41,0,43$ and $0,41 \mathrm{~g}$ of $\mathrm{P}$ per plant, respectively (Figure 2A, B, C and D).

With regard to the accumulation of $K$ in the leaves, it was observed that the highest accumulations were obtained in the highest nutrient concentration (150\%), applied in the ratios 100/0, 25/75 and 0/100, with values of 2,44, 2,63 and 2,78 g per plant, respectively. It may be observed that even in the lower concentrations the ratios with higher amounts of organic fertilizers provided the higher accumulation of $K$ in the leaves. Given these results, it is observed that the exportation of macronutrients by the leaves was superior to the stem, especially for potassium, what may be explained due to the important functions developed by this nutrient in
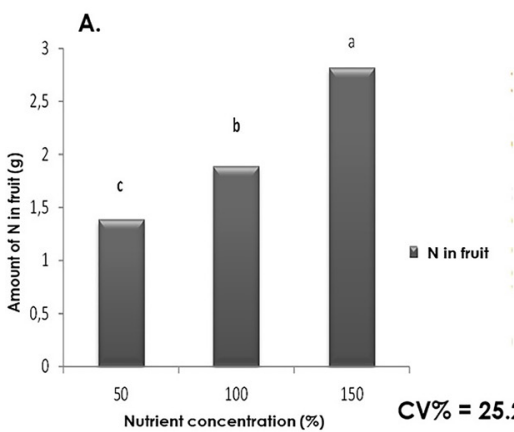

$\mathrm{CV} \%=25.20$

C.

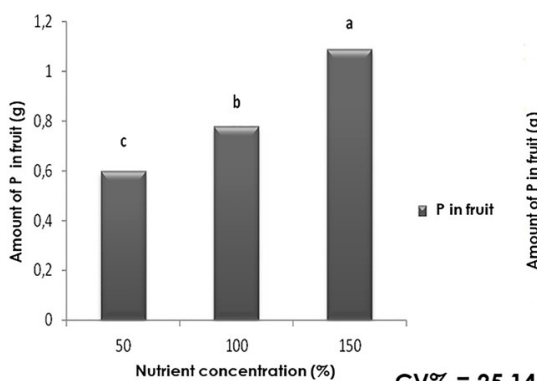

$\mathrm{CV} \%=25.14$

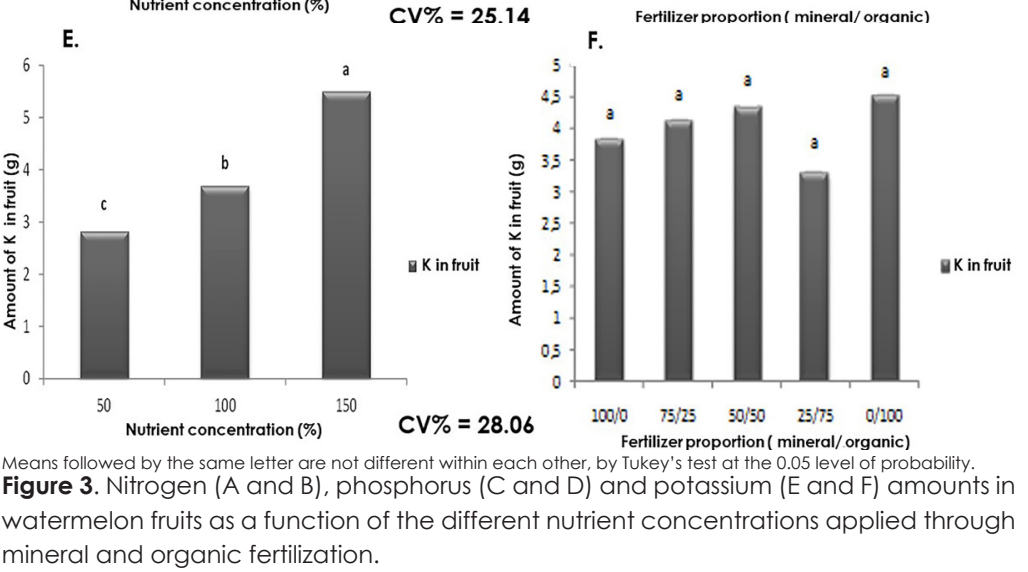

Means followed by the same letter are not different within each other, by Tukey's test at the 0.05 level of probability.

Figure 3. Nitrogen ( $A$ and $B$ ), phosphorus ( $C$ and $D$ ) and potassium ( $E$ and $F$ ) amounts in watermelon fruits as a function of the different nutrient concentrations applied through mineral and organic fertilization. others (Taiz \& Zeiger, 2009). per plant (Figure 3E).

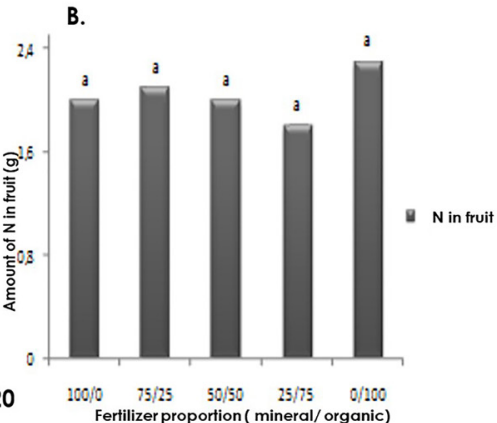

D.

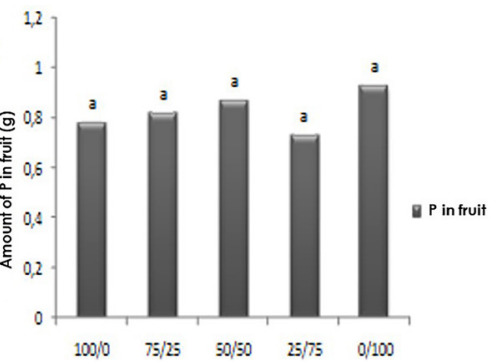

physiological processes that occur in this organ, such as photosynthesis, enzymatic activation, protein synthesis, carbohydrate transport, among

With regard to the accumulation of the $\mathrm{N}, \mathrm{P}$ and $\mathrm{K}$ macronutrients in watermelon fruits, it was verified that there was no significant interaction between the studied factors. An individual significant effect was only verified for the factor nutrient concentration (Figure 3). The accumulation of macronutrients was higher as a function of the increase in the concentration of fertilizers. For the $N$, the accumulation of 1,39, 1,89 and 2,82 g per plant was verified, respectively, for the concentrations of 50,100 and $150 \%$ (Figure $3 \mathrm{~A})$. With regard to the $P$, a similar result to the $\mathrm{N}$ was verified, in which the $\mathrm{P}$ accumulation was of 0,6, 0,78 and 1,09 $\mathrm{g}$ per plant (Figure 3C). The same result was also verified for the accumulation of $K$, in which the values were 2,82, 3,69 and 5,5 $\mathrm{g}$

Com. Sci., Bom Jesus, v.x, n.x, p.x-x, xxx./xxx. 2018 
According to the results, it is observed that the decreasing accumulation order of macronutrients in the fruits follows the same order of the vegetative part for $K, N$ and $P$, respectively. Generally, the fruits were responsible for the higher exportation of macronutrients, being responsible for $52,5 \%$ of $K, 54,6 \%$ of $N$ and $57,9 \%$ of $\mathrm{P}$. Higher accumulations of macronutrients in the fruits were also observed by other authors for watermelon(Grangeiro \& Cecílio Filho, 2005) and in other fruit vegetables (Vidigal et al., 2007, 2009).

When evaluating the watermelon commercial production, a significant interaction was verified between the factors nutrient concentrations and ratio of mineral and organic

fertilizers (Figure 4). When performing the unfolding of the interaction, a higher production was observed in the treatments subjected to $150 \%$ of the nutrient concentration, when applied in the $75 / 25,25 / 75$ and $0 / 100$ ratios (mineral/ organic). For the remaining ratios, no difference was verified between the concentrations of 100 and $150 \%$ (Figure $4 \mathrm{~A}$ ). For the fertilization with manure only $(0 / 100)$, the productions in the concentrations of $100 \%\left(57,500 \mathrm{Kg} \mathrm{ha}^{-1}\right)$ and $150 \%$ $\left(56,858 \mathrm{Kg} \mathrm{ha}^{-1}\right)$ were not significantly different. For the $100 \%$ concentration the $50 / 50$ and $0 / 100$ ratios provided the highest productions. Conversely, in the concentration of $150 \%$ the most pronounced ratio was $75 / 25$ (Figure $4 B$ ).

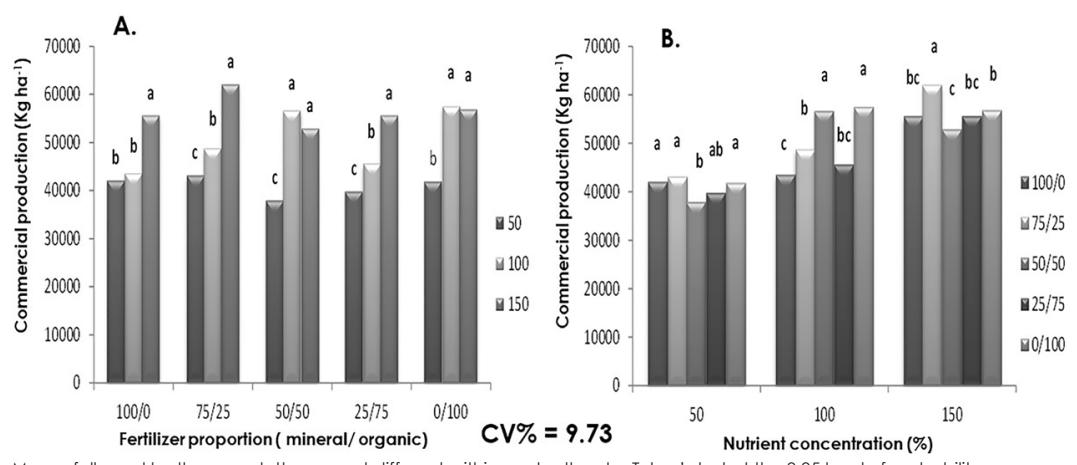

Means followed by the same letter are not different within each other, by Tukey's test at the 0.05 level of probability.

Figure 4. Commercial production of water melon fruits ( $A$ and $B$ ) as a function of different nutrient concentrations applied through mineral and organic fertilization.

It is believed that the presence of the organic fertilizer provides decrease in the losses through volatilization, lixiviation or immobilization of nutrients, what might have contributed for the obtaining of high watermelon productions even in the highest manure ratios. According to Pires and Junqueira (2001) organic fertilization, besides being an important source of nutrients, especially $N, P, S$ and micronutrients, is the only $\mathrm{N}$ storing alternative that is not lost through volatilization, being yet responsible for $80 \%$ of the total phosphorus found in the soil. There is a consensus among several authors about the efficiency of the bovine manure, whether or not associated to mineral fertilizers, in elevating vegetable production. Fernandes et al. (2003) obtained higher melon yields as a function of the application of organo-mineral fertilizers, with production of $45,500 \mathrm{Kg} \mathrm{ha}^{-1}$ of fruits, superior to the $42,400 \mathrm{Kg} \mathrm{ha}^{-1}$ obtained with mineral fertilizers. Bertol et al. (2010) observed that the application of organic fertilizer, compared to the mineral fertilizer, increased the concentrations of total $P$, particulate $P$ and dissolved reactive $P$ in the surface of the soil.

Leão et al. (2008), studying different levels of organic and chemical fertilization observed a lower watermelon yield (Crimson Sweet) when these were used in isolate. Mueller et al. (2013) in his studies with organic fertilizer with and without mineral fertilization on tomato observed higher commercial yields obtained with the application of the mineral fertilization only, or with the application of the organic fertilizer complemented with mineral fertilizer.

No significant effect was verified for the titratable acidity and for the ratio between soluble solids and titratable acidity (SS/TA) as a function of the evaluated treatments. For the soluble solids content a significant interaction was verified between the nutrient concentrations and the different ratios of organic and mineral 
fertilizer (Figure 5). The highest SS contents were obtained in the 100 and $150 \%$ concentrations for all ratios, not differing, although, of the $50 \%$ concentration in the ratios of 100/0,25/75 and $0 / 100$ (mineral/organic) (Figure 5A). The SS values observed were below the minimum content acceptable by the consuming market, which according to the literature is 10\% (Barros et al., 2012). However, according to Leão et al. (2006), there is a varied spatial distribution of the SS content in the watermelon pulp, being higher in the center of the fruit and gradually decreasing as it approaches of the rind, partly justifying the low contents observed, due to the fact that this
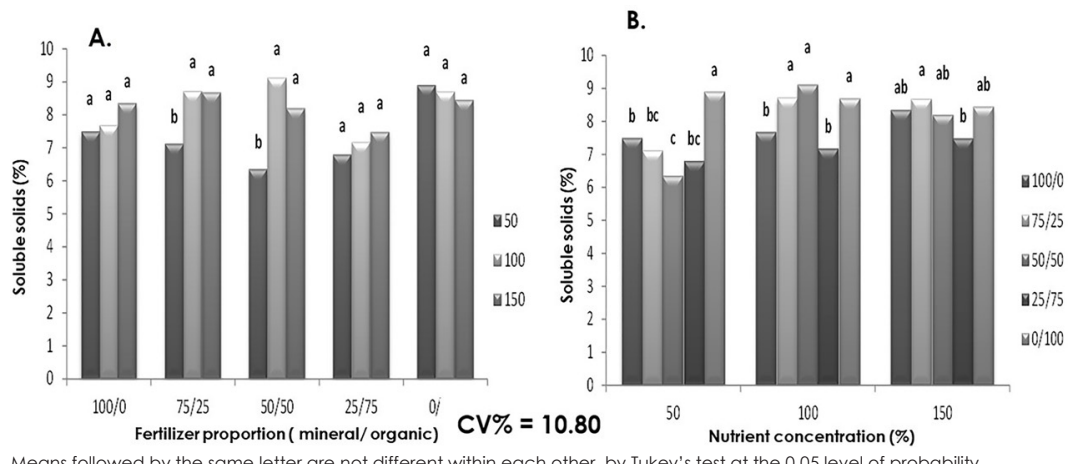

other, by Tukey's test at the 0.05 level of probability.

Figure 5. Soluble solids (A and B) in watermelon fruits as a function of the different nutrient concentrations applied through mineral and organic fertilization.

\section{Conclusions}

The $150 \%$ concentration of the recommended dose, in all evaluated ratios, was the most effective for the NPK accumulation in the vegetative part of the watermelon plant;

Fruits were the preferable NPK drains compared to the vegetative part;

The $150 \%$ nutrient concentration was the most effective in the increase of yield in the ratios of mineral and organic fertilizers of 75/25, 25/75 and $0 / 100$;

The 100 and $150 \%$ concentrations were the most effective in the accumulation of total soluble solids when combined with the ratios of mineral and organic fertilizers of $75 / 25$ and 50/50.

\section{References}

Albuquerque A.W.,Rocha E.S.,Costa J.V.,Farias A.P.,Bastos A.L. 2010. Produção de helicônia Golden Torch influenciada pela adubação mineral e orgânica. Revista Brasileira de Engenharia Agrícola e Ambiental 14: 1052-1058.

Barros, M.M., Araújo, W.F., Neves, L.T.B.C., Campos, A.J.,Tosin J.M. 2012.Produção e qualidade da melancia submetida a adubação measure was determined in a juice originated from a mixture of different pulp parts.

The fertilization with manure only favored the accumulation of SS in watermelon fruits in the concentrations of 50 and $100 \%$ of nutrients when compared to the mineral fertilization, with an increment of 18.6 and $13.3 \%$, respectively. For tomato, Polat et al. (2010) observed that the organic fertilization resulted in a higher fruit quality, when compared to the mineral fertilization, suggesting that it must be maintained in order to ease the elimination and reutilization of organic residues, as well as to maintain and/or increase soil fertility.

nitrogenada. Revista Brasileira Engenharia Agrícola e Ambiental16: 1078-1084.

Bertol, O.J., Rizzi, N.E., Favaretto, N., Lana, M.C. 2010.Phosphorus loss by surface runoff in no-till system under mineral and organic fertilization. ScientiaAgricola 67: 71-77.

Carvalho J.S.B.,Martins J.D.L.,Ulisses C.,Silva W.L. 2012. Adubação orgânica, mineral e organomineral e sua influencia no crescimento da helicônia em Garanhuns-PE. Horticultura Brasileira 30: 579-583.

Cavalcante, F.J.A. 2008.Recomendação de adubação para o estado de Pernambuco: $2 a$ aproximaçãolPA, Recífe, Brasil.198p.

Fernandes, A.L.T., Rodrigues, G.P.,Testezlaf.2003. Mineral and organomineralfertirrigation in relation to quality greenhause cultivated melon. Scientia Agrícola 60: 149-154.

Furtini Neto, A.E., Vale, F.R., Resende, A.V., Guilherme, L.R.V., Guedes, G.A.A. 2001. Fertilidade do solo,UFLA/FAEP, Lavras, Brasil, 252p.

Galvão, S.R.S,Salcedo, I.H.,Oliveira, F.F. 2008. Acumulação de nutrientes em solos arenosos adubados com esterco bovino. Pesquisa Agropecuária Brasileira 43: 99-105. 
Grangeiro, L.C., Cecílio Filho, A.B. 2005. Acúmulo e exportação de macronutrientes em melancia sem sementes. Hoticultura brasileira 23: 763-767.

Guppy, C.N.,Menzies, N.W., Moody, P.W.,Blamey, F.P.C. 2005.Competitive sorption reactions between phosphorus and organic matter in soil: a review. Australian Journal of Soil Research 43: 189-203.

Leão, D.S.S., Peixoto, J.R., Vieira, J.V. 2006. Teor de licopeno e de sólidos solúveis totais em oito cultivares de melancia. BioscienceJournal 22: 7-15.

Leão, D.S.S., Peixoto, J.R.,Vieira, J.V., Cecílio Filho, A.B. 2008.Produtividade de melancia em diferentes níveis de adubação química e orgânica. Bioscience Journal24:32-41.

Menezes, R.S.C.,Salcedo. I.H. 2007. Mineralização de $\mathrm{N}$ após incorporação de adubos orgânicos em um NeossoloRegolítico cultivado com milho. Revista Brasileira de Engenharia Agrícola e Ambiental1 1: 361-367.

Mueller, S., Wamser, A.F., Suzuki, A., Becker, W.F. 2013.Produtividade de tomate sob adubação orgânica e complementação de adubos minerais. Horticultura Brasileira31: 86-92.

Naeem, M., lqbal,J.,Bakhshm, M.A.A. 2006. Comparative Study of Inorganic Fertilizers and Organic Manures on Yield and Yield Components of Mungbean (Vignaradiat L.). Journal Agriculture Society Science2: 227-229.

Ouda, B.A.,Mahadeen, A.Y. 2008. Effect of Fertilizers on Growth, Yield, Yield Components, Quality and Certain Nutrient Contents in Broccoli (Brassica oleracea).International Journal of Agriculture \& Biology 10:627-232.

Pires, J.F., Junqueira, A.M.R. 2001. Impacto da adubação orgânica na produtividade e qualidade das hortaliças. HorticulturaBrasileira 19: 195-202.

Polat, E.,Demir, H.,Erler, F. 2010. Yield and quality criteria in organically and conventionally grown tomatoes in Turkey.Scientia Agrícola67: 424-429.

Rodrigues, E.T., Casali, V.W.D. 1999.Rendimento e concentração de nutrientes em alface, em função das adubações orgânica e mineral. Horticultura Brasileira 17:125-128.

Rodrigues, G.S.O., Torres, S.B., Linhares, P.C.F., Freitas, R.S., Maracajá. P.B. 2008. Quantidade de esterco bovino no desempenho agronômico da rúcula (Eruca sativa L.), cultivar cultivada. Caatinga 21: 162-168.

Santos, M.R., Sediyama, M.A.N., Moreira, M.A., Megguer, C.A., Vidigal, S. M. 2012. Rendimento, qualidade e absorção de nutrientes pelos frutos de abóbora em função de doses de biofertilizante. Horticultura brasileira 30: 160-167.

Silva, F.C. 2009. Manual de análises químicas de solos, plantas e fertilizantes. $2^{\circ}$ ed. revisada e ampliada. Embrapa Informação Tecnológica, Brasília, Brasil. 627 p.

Taiz, L.,Zeiger, E. 2009. Fisiologia vegetal. $4^{a}$ ed. Artmed,Porto Alegre, Brasil. 819 p.

Vidigal, S.M., Pacheco, D.D., Costa, E.L. Facion, C. 2009. Crescimento e acúmulo de macro e micronutrientes pela melancia em solo arenoso. Revista Ceres 56: 112-118.

Vidigal, S.M., Pacheco, D.D., Facion, C.E. 2007. Crescimento e acúmulo de nutrientes pela abóbora híbrida tipo Tetsukabuto. Horticultura Brasileira25: 375-380. 